\title{
O GREENSTONEBELTDO RIO ITAPICURU: UMA BACIA DO TIPO BACK-ARC FÓSSIL
}

\author{
MARIA G. SILVA*
}

\begin{abstract}
THE RIO ITAPICURU GREENSTONE BELT (BAHIA): A FOSSIL BACK-ARC BASIN. A model for the geotectonic evolution of the Rio Itapicuru granite-greenstone terrain is proposed herein, based on the integration of geochemical, metamorphic and structural data. Although spilitized, the basalts preserved geochemical signatures typical of ocean floor tholeiites (OFB). They show flat to enriched patterns of LREE, and flat patterns of HREE contrasting with negative and low values of epsilon $\mathrm{Nd}$, thus, pointing to an environment compatible with a marginal basin. The andesitic and dacitic lavas and pyroclastics display a calc-alkaline affiliation, and were formed, at least in part, in a subaerial environment similar to a continental margin volcanic arc. The sintectonic granite-gneiss domes show calc-alkaline affiliation, with an origin in the mantle. The entire sequence was affected by one main deformational event related to the closure of the basin and the emplacement of the granite-gneiss domes resulting in a sinformal structure. The metamorphic grade varies from amphibolite at the margins grading to greenschist facies in the center. Geochronological studies point to the existence of an Archaean basement ( $2.9 \mathrm{Ga})$. The supracrustal sequence however, has An early Proterozoic age (2.5-1.8 Ga). These characteristics support the interpretation of the Rio Itapicuru greenstone belt as a supracrustal sequence accumulated in a back-arc basin, related to a collision/subduction process at the begining of the Proterozoic.
\end{abstract}

Keywords: Greenstone belt, volcanosedimentary sequences, back-arc basin, São Francisco craton, Bahia, Brazil, Early Proterozoic, tholeiites, calc-alkalines, active margins, turbidites, granites, komatiites.

\begin{abstract}
RESUMO Com base na integração dos dados geoquímicos, metamórficos e estruturais, propõe-se um modelo de evolução geotectônica para o Greenstone Belt do Rio Itapicuru (Bahia). As rochas basálticas apresentam feições compatíveis com toleftos de fundo oceânico (OFB), com características transicionais entre MORB e IAT. As lavas e piroclásticas andesíticas a dacíticas são de filiação cálcio-alcalina, com características geoquímicas e isotópicas compatíveis às de andesitos dos modernos ambientes de margens continentais ativas. Os granitóides sintectônicos são geoquimicamente similares aos vulcanites félsicos e intermediários. Toda a seqüência foi afetada por um evento metamórfico de natureza dinamotermal, resultante do fechamento da bacia e da colocação dos domos granitognáissicos. O fechamento da bacia é responsável também pelo padrão de deformação sinformal da seqüência, de zonas contínuas de cisalhamento paralelas ao eixo maior da sinforme e de pequenas estruturas de cavalgamento. O grau metamórfico varia da fácies anfibolito, nas bordas da seqüência, à fácies xisto verde, no centro. Estudos geocronológicos apontam para uma idade proterozóica inferior (Transamazônica) para o terreno granito-greenstone e uma idade arqueana para os terrenos migmatito-gnáissicos circundantes. As características gerais dão suporte à interpretação de que os terrenos granito-greenstone do Rio Itapicuru tenham sido gerados num ambiente similar às modernas bacias de back-arc, resultantes de uma tectônica de colisão-subducção.
\end{abstract}

Palavras-chaves: Greenstone belt, seqüência vulcanossedimentar, bacia de back-arc, Craton do São Francisco, Bahia, Brasil, Proterozóico Inferior, toleítos, cálcio-alcalinas, margens continentais ativas, turbiditos, granitos, komatiítos.

INTRODUÇÃOO O terreno granito-greenstone da Região do Médio Itapicuru, no Estado da Bahia, abrange uma área superior a $7500 \mathrm{~km}^{2}$, limitada pelos paralelos $38^{\circ} 55^{\prime}$ e $39^{\circ} 35^{\prime}$ oeste e pelos meridianos $10^{\circ} 10^{\prime}$ e $11^{\circ} 35^{\prime}$ sul (Fig. 1).

As rochas supracrustais desse terreno, com espessura de aproximadamente $9,5 \mathrm{~km}$, compreendem rochas vulcânicas máficas (na base), rochas vulcânicas intermediárias a félsicas, além de sedimentos elásticos e químicos, tanto intercalados nas rochas vulcânicas como formando um pacote individualizado no topo da seqüência.

As intrusivas são predominantemente granitóides de natureza sin e pós-tectônica, embora ocorram, subordinadamente, sills gabróicos e corpos subvulcânicos intermediários a félsicos. Apenas um corpo ultramáfico, de posicionamento duvidoso, foi encontrado até o momento nesses terrenos.

Duas fases de deformação afetaram a seqüência Silva \& Matos 1991). A fase inicial (D1) foi resultante de uma tectônica tangencial, concomitante ao fechamento da bacia e diapirismo granítico. A esta fase estão relacionados os eventos $\mathrm{Fl}$, de deformação cisalhante de trend
N-S e o evento F2, responsável pelo desenvolvimento de uma sucessão de anticlinaís e sinclinais, de eixo N-S e vergência para leste. A fase D2 está representada por um dobramento de grande amplitude, que afetou também o embasamento e cujo fechamento se encontra na porção sul da estrutura greenstone.

Três eventos metamórficos distintos afetaram a seqüência (Silva 1983, 1987): 1. um evento inicial, de natureza hidrotermal (Ml), de fundo oceânico, que espilitizou parcialmente as rochas vulcânicas; 2. um evento subsequente regional (M2), progressivo, da facies xisto verde a anfibolito, sin F2 e concomitante com a colocação dos granitos sin-tectônicos; e 3. um evento final (M3) de natureza termal, localizado em torno dos corpos intrusivos pós-tectônicos.

Todo o conjunto encontra-se encravado em rochas gnáissico-migmatíticas arqueanas do embasamento do Cráton do São Francisco (Almeida 1977).

Muito embora o contato entre as supracrustais e os terrenos gnáissico-migmatíticos não tenha sido diretamente observado, estudos do comportamento metamórfico bem como 


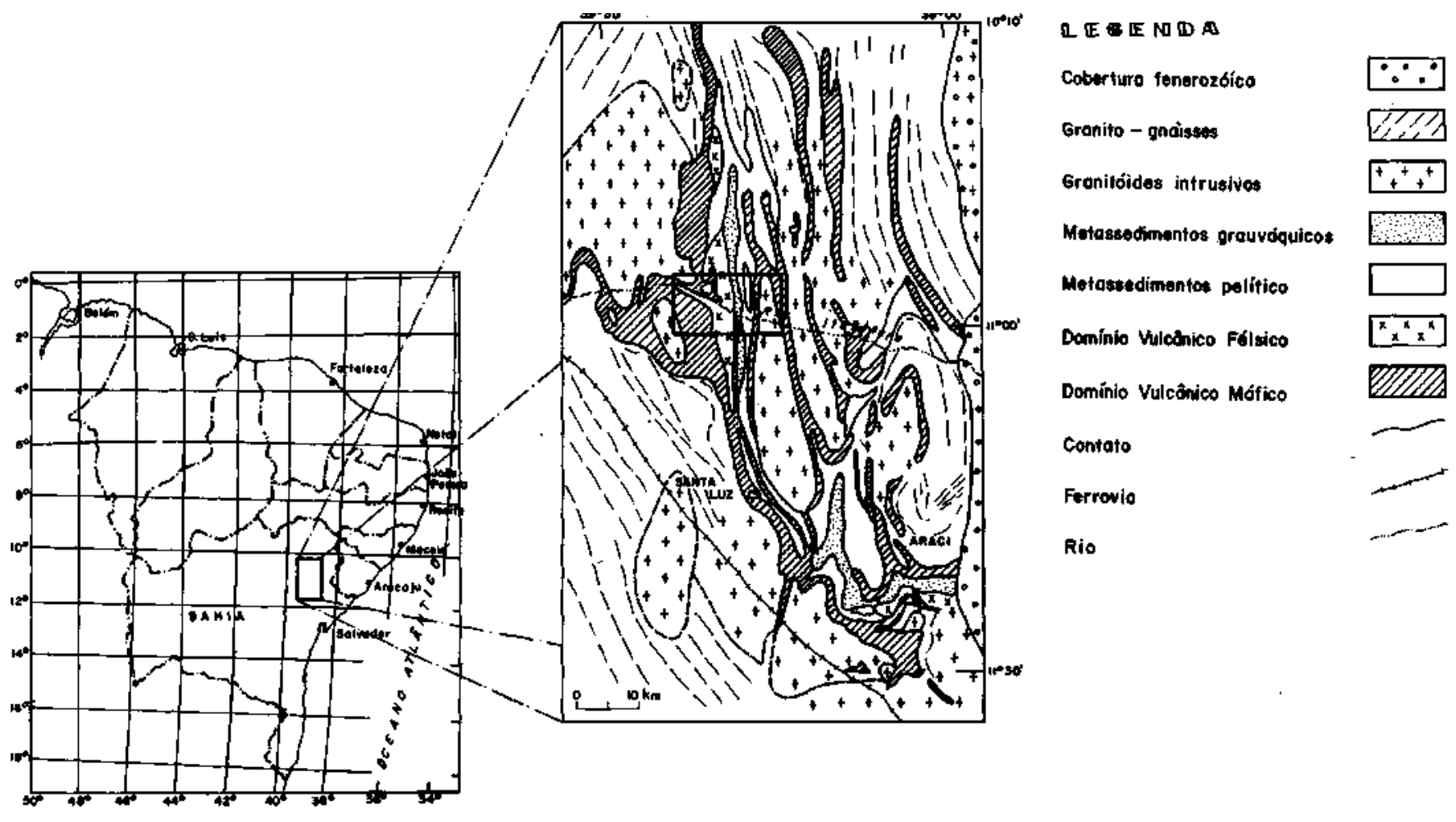

Figura 1 - Mapas de localização e geológico simplificados do Greenstone Belt do Rio Itapicuni. Quadro localizando a área da figura 2, selecionada para estudos petrográficos e litogeoquímicos de detalhe

Figure 1 - Location and simplifyed geological map of the Rio Itapicuru Greenstone Belt. Quadrangle refers to the area from figure 2

do padrão de deformação apontam para a existência de forte descontinuidade entre esses dois domínios (Davison et al. 1988). Essas evidências indiretas, somadas aos resultados geocronológicos até o momento obtidos para as rochas dessa área $(2,9 \mathrm{Ga}$ para as rochas gnássico-migmatíticas e 1,8 Ga para os granitóides sin-tectônicos, Gáal et al, em elaboração); 2,1 Ga para os andesitos e 2,2 Ga para os basaltos da seqüência supracrustal, M.G. Silva, em elaboração), sugerem que as rochas gnáissico-migmatíticas sejam o embasamento da seqüência supracrustal.

Para a realização de estudos geoquímicos nos diferentes litotipos do conjunto granito-greenstone, foi selecionada uma área de aproximadamente $150 \mathrm{~km}^{2}$, localizada ao longo do Rio Itapicuru, em seu curso médio (Fig. 2), onde a exposição contínua das rochas facilitou o trabalho de amostragem. Essa área compreende um sinclinal deitado cujo anticlinal adjacente é ocupado pelo corpo granitóide sintectônico do Ambrósio.

Este trabalho teve por objetivos: 1. a definição da afinidade geoquímica das diferentes rochas supracrustais; 2 . a identificação do ambiente geotectônico no qual essas rochas foram geradas e dos processos envolvidos na gênese; 3. propiciar uma discussão, ainda que de caráter preliminar, acerca das relações entre o terreno granito-greenstone e os terrenos metamórficos de alto grau adjacentes, e, por fim 4. a proposição de um modelo de evolução para essa porção do Cráton do São Francisco.

ROCHAS VULCÂNICAS MARCAS Aspectos macro e microscópicos A porção basal da seqüencia supracrustal consiste em um pacote, de aproximadamente $5 \mathrm{~km}$ de espessura, de rochas vulcânicas máfícas, compreendendo basaltos maciços (predominantes), basaltos porfiríticos, basaltos variolíticos, basaltos amigdaloidais e brechas de fluxo. Em alguns locais aparecem estruturas do tipo pillow-lava muito bem preservadas.
As vulcânicas máfícas situam-se nas bordas da estrutura sinclinal, ocupando cerca de $60 \%$ da área de exposição do greenstone.

Nas porções marginais, onde o grau metamórfico corresponde à fácies anfibolito do evento $\mathrm{M} 2$, esses basaltos apresentam a paragênese hornblenda+plagioclásio cálcico. Na transição das bordas para o centro da seqüência a paragênese é do tipo hornblenda actinolítica+oligoclásio+epidoto+carbonato+ titanita, típica da fácies epidoto anfibolito do evento M2. No centro do greenstone, onde as rochas foram menos afetadas pelo evento tectono-termal de fechamento da bacia, as paragêneses resultantes do evento $\mathrm{Ml}$ não foram significativamente obliteradas pelas reações metamórficas do evento M2, sendo ainda facilmente reconhecíveis feições relativas ao evento de espilitização. Predomina nesta porção do greenstone a paragênese actinolita+clorita+albita+carbonato+quartzo+epídoto+"leucoxênio", pertencente à fácies xisto verde de metamorfismo.

Nos basaltos variolíticos as variolas possuem no máximo $1,5 \mathrm{~cm}$ de diâmetro e consistem num aglomerado de cristais de plagioclásio+quartzo+carbonato. Esta textura foi interpretada por Silva (1983) como decorrente de um fenômeno de imiscibilidade de líquidos.

As pillows possuem desde $15 \mathrm{~cm}$ até $2 \mathrm{~m}$ de diâmetro e apresentam margens afaníticas e fraturas radiais, feições indicativas de resfriamento brusco. O material inter-pillow é basáltico afanítico, tendo sido totalmente espilitizado pelo evento metamórfico de fundo oceânico, como evidenciado nos afloramentos menos afetados pelo evento M2 de metamorfismo.

Os basaltos porfiríticos, raros na seqüência, apresentam antigos fenocristais de piroxênio, totalmente transformados em anfibólio.

As brechas de fluxo associam-se aos derrames em almofadas. Consistem em fragmentos de tamanho variado de lava basáltica maciça, englobados por lava basáltica afanítica fortemente espilitizada. 


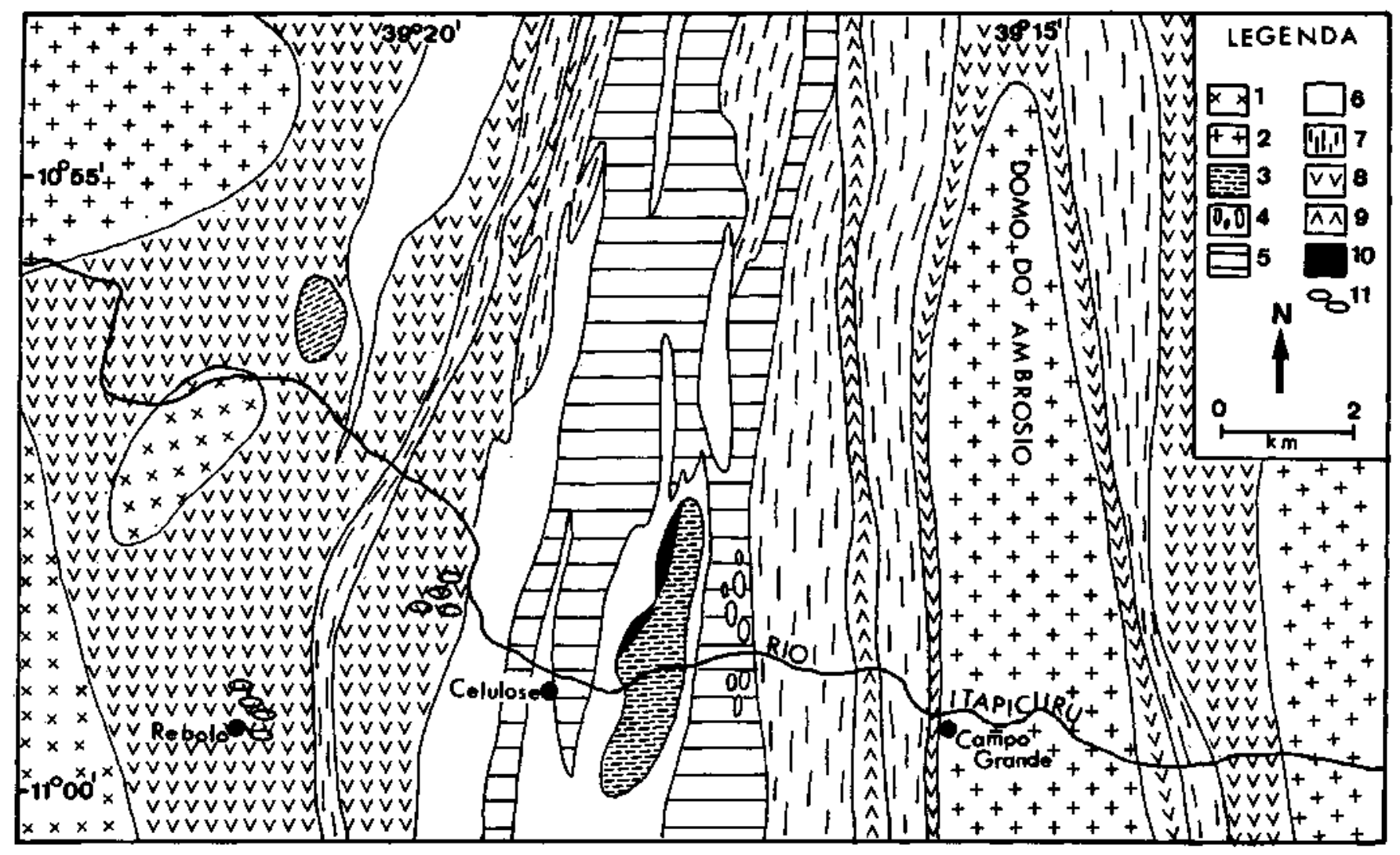

Figura 2 - Mapa geológico da porção central do Greenstone Belt do Rio Itapicuru. 1. Granitóides pós-tectônicos; 2. Granitóides sin-tectônicos; 3. Corpos félsicos subvulcânicos; 4. Aglomerados vulcânicos félsicos; 5 . Tufos andesíticos e dacíticos; 6. Lavas andesíticas e dacíticas; 7. Sedimentos elásticos e pelíticos; 8. Basaltos toleíticos; 9. Gabros; 10. Rochas ultramáficas; 11. Pillow-lavas

Figure 2 - Geological map of the central part of the Rio Itapicuru Greentone Belt 1. Post-tectonic granitoids; 2. syn-tectonic granitoids; 3. Felsic subvolcanic bodies; 4. Felsic agglomerates; 5. Andesitic and dacitic tuffs; 6. Andesitic and dacitic lavas; 7. Clastic sediments; 8. Tholeiitic basalts; 9. Gabbros; 10. Ultramafics; 11. Pillow-lavas

Geoquímica Silva (1987) realizou análises químicas de elementos maiores e traços, por fluorescência de raios X, em um grupo selecionado de amostras de basaltos (53), peridotitos (30), andesitos e dacitos (15) e granitos (23). Dentro desse grupo foram ainda selecionadas, sete amostras de basaltos, seis amostras de peridotitos e duas amostras de andesitos para análises, por ICP, de elementos terras-raras.

Os resultados dessa análises revelaram as seguintes características gerais para os metabosaltos:

1. os teores de $\mathrm{SiO}_{2}$ situam-se entre 45 e $55 \%, \mathrm{TiO}_{2}$ entre 0.5 e $2.0 \%$ e o somatório de álcalis não ultrapassa $3 \%$. O Fe-total (calculado como $\mathrm{Fe}_{2} \mathrm{O}_{3}$ ) oscila entre 10 e $17 \%$, enquanto os valores de $\mathrm{MgO}$ situam-se entre 4,5 e 7,54\%;

2. todas as amostras possuem quartzo e hiperstênio normativos sendo portanto supersaturadas em sílica;

3. predominam basaltos com teores de Fe-total acima de $12 \%$, que podem ser classificados, de acordo com BVSP (1981), como ferro basaltos;

4. os basaltos são tipicamente de ambiente oceânico, como evidenciado pelo diagrama da figura 3 , e pertencem à série toleítica de diferenciação, caracterizada por um enriquecimento contínuo em ferro, paralelamente a um empobrecimento em magnésio (Figs. 4a e 4b), no decurso da diferenciação magmática;

5. os padrões de ETR (elementos terras-raras) apontam para a existência de dois derrames basálticos distintos: os basaltos tipo I (Fig. 5a), caracterizados por apresentarem padrões planos de terras raras, tanto no domínio das terras-raras leves (TRL) quanto no das terras-raras pesadas (TRP), e os basaltos tipo II (Fig. 5b) com um leve enriquecimento das TRL em relação às TRP; e
6. quanto à origem dessas rochas, foi demonstrado por Silva (1987), com base em cálculos petrogenéticos, que os basaltos tipo I e II são diferenciados de líquidos distintos, gerados a partir de diferentes percentuais de fusão de uma mesma fonte mantélica

$\mathrm{TiO}_{2}$

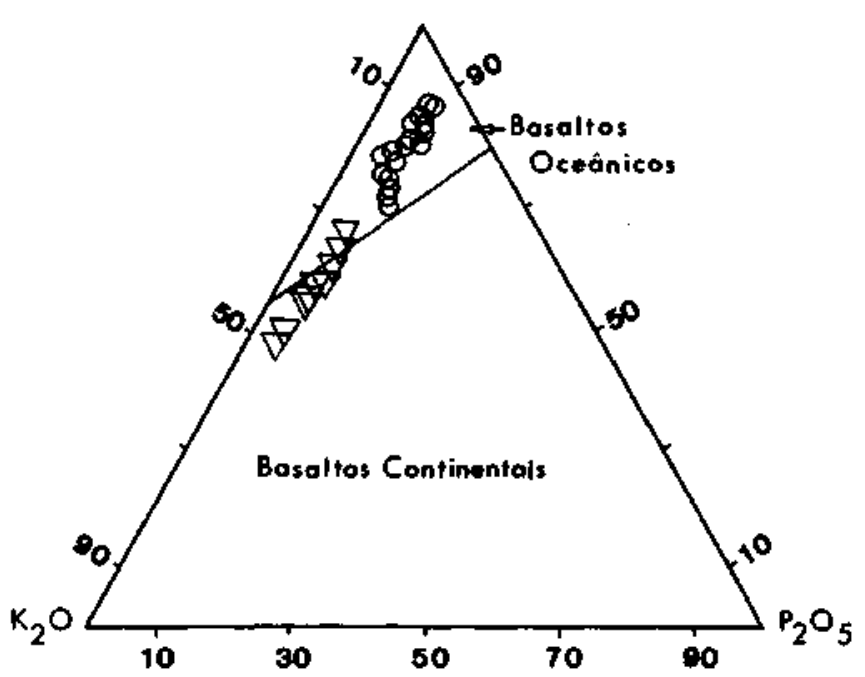

Figura 3 -Basaltos do Rio Itapicuru ocupando o campo dos basaltos oceânicos no diagrama $\mathrm{TiO}_{2}-\mathrm{K}_{2} \mathrm{O}-\mathrm{P}_{2} \mathrm{O}_{s}$ proposto por Pearce et al. (1975)

Figure 3 - The $\mathrm{TiO}_{2}-\mathrm{K}_{2} \mathrm{O}-\mathrm{P}_{2} \mathrm{O}_{5}$ diagram (from Pearce et al. 1975) showing the Rio Itapicuru basalts occupying the ocean floor basalt (OFB) field 

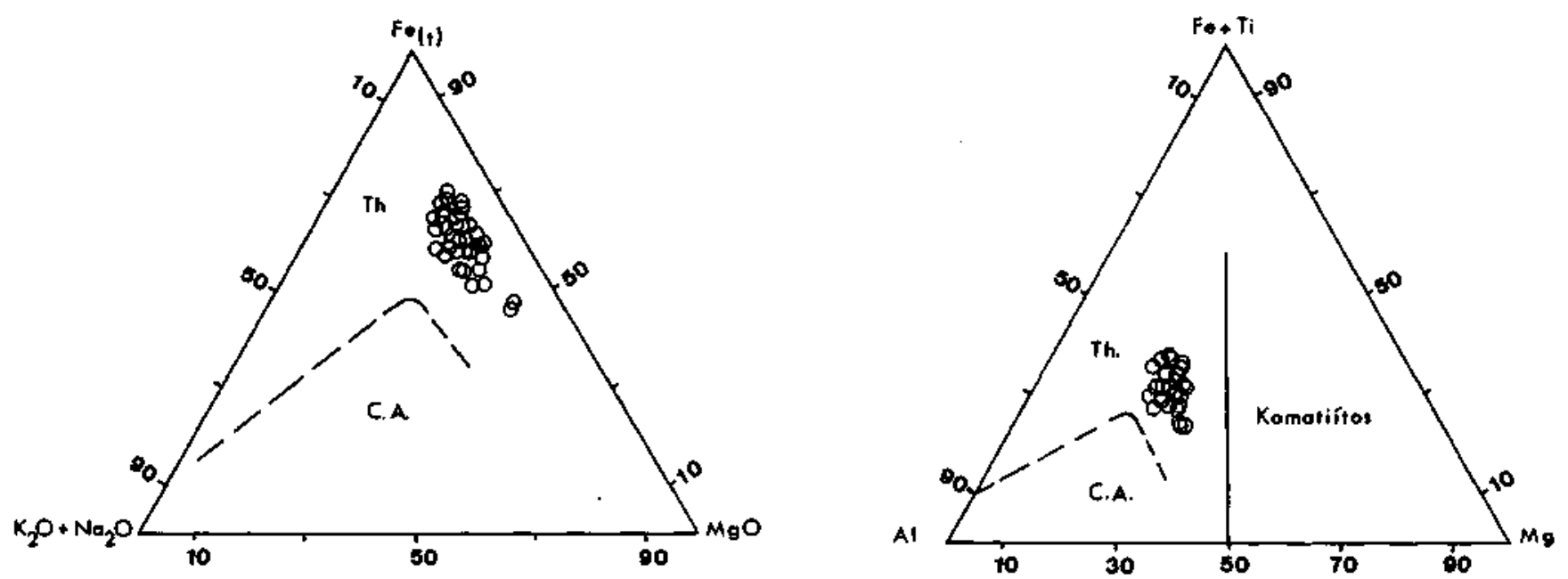

Figura 4- a. Diagrama AFM e b. Diagrama de Jensen. Basaltos do Rio Itapicuru ocupando os campos reservados a basaltos de filiação toleitica. C.A. (cálcio-alcalinas), Th (toleitos)

Figure 4 - a. AFM diagram and b. Jensen Plot showing the Rio Itapicuru basalts in the tholeiitic field. C.A. (calc-alkalines), Th (tholeiites)

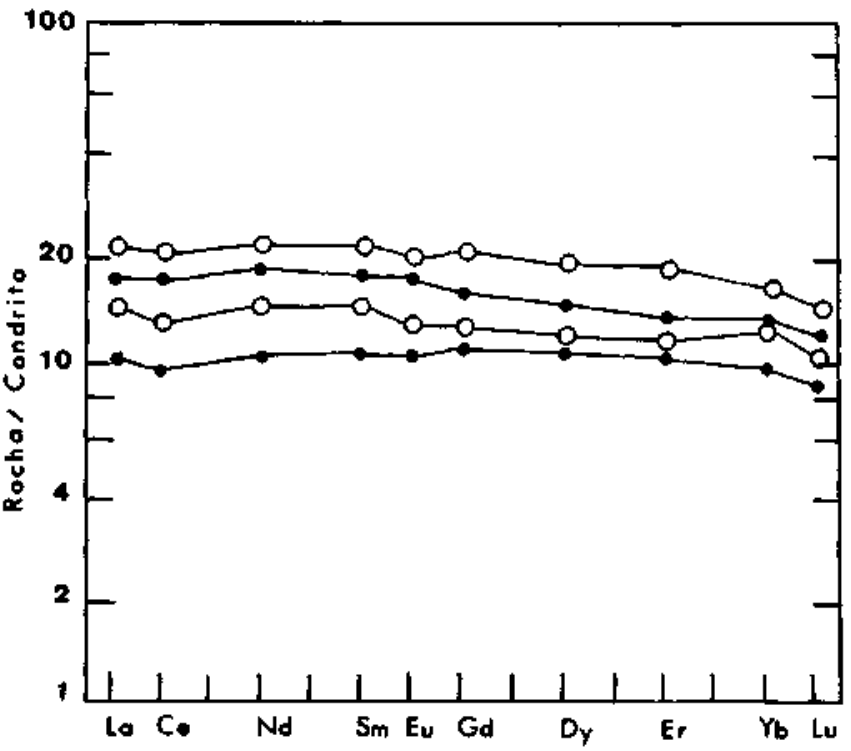

Figura 5 a - Valores normalizados de terras-raras de basaltos do tipo I

Figure 5a - Chondrite-normalized rare earth elements pattern for the type I basalts

De acordo com BVSP (1981), basaltos oceânicos podem ser gerados em ambientes de tectônica de colisão (toleítos de arcos de ilhas), em ambientes de tectônica de extensão (cadeias mesoceânicas e bacias de back-arc) e em ambientes intraplacas oceânicos, anorogênicos (basaltos de ilhas oceânicas).

Visando definir o ambiente de formação das rochas basálticas do Rio Itapicuru, diagramas discriminatórios foram construídos utilizando-se basicamente os elementos que se demonstraram menos susceptíveis aos processos secundários.

Vale aqui ressaltar que foi feita uma análise do comportamento dos elementos maiores e traços, diante dos processos secundários (Silva 1987), tomando por base diagramas de razões moleculares (DRM) propostos por Pearce (1968), usando $\mathrm{P}_{2} \mathrm{O}_{5}$ como oxido normalizador. $\mathrm{A}$ escolha do $\mathrm{P}_{2} \mathrm{O}_{5}$ deve-se à inexistência de apatita nas rochas basálticas dessa porção do Itapicuru, o que permitiu assumir que não houve fracionamento do fósforo.

De acordo com o diagrama de Pearce \& Cann (1973), os basaltos do Itapicuru pertencem ao grupo dos toleítos de baixo

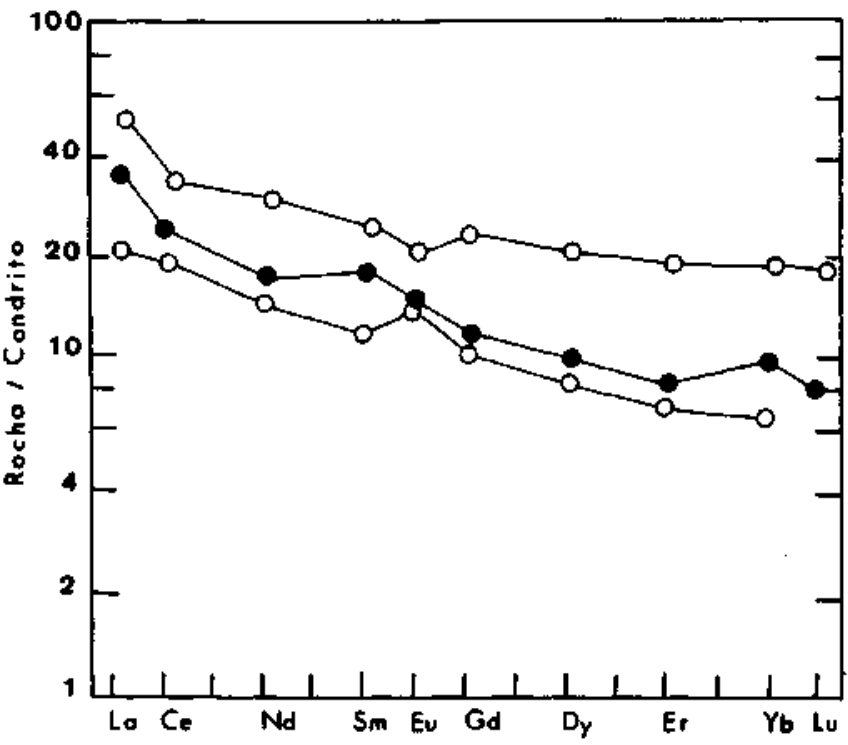

Figura 5 b - Valores normalizados de terras-raras de basaltos do tipo II

Figure $5 \mathrm{~b}$ - Chondrite-normalized rare earth elements pattern for the type II basalts

K (Fig. 6), típicos tanto de ambientes de fundo oceânico (OFB) quanto de arcos de ilhas (IAT). A natureza exclusiva de fundo oceânico desses basaltos fica entretanto evidente nos diagramas das figuras $7 \mathrm{a}$ e $7 \mathrm{~b}$, construídos de acordo com Pearce (1975) e Garcia (1978), respectivamente.

Basaltos de fundo oceânico podem ser gerados tanto em cadeias mesoceânicas (MORB), quanto em bacias do tipo back-arc, sendo, em ambos os casos, produtos de uma tectônica de extensão.

Do ponto de vista geoquímico, basaltos de ambientes tipo MORB e de bacias do tipo back-arc são bastante semelhantes, o que levou alguns autores, exemplo de Jahn (1986), a propor uma classificação única para ambos os tipos. Entretanto, Hawkesworth et al (1977), Sounders \& Tarney (1979) e Jahn (1986), ao realisarem trabalhos geoquímicos sistemáticos em basaltos de bacias do tipo back-arc, constataram a ausência, nesse tipo de ambiente, de rochas com padrões empobrecidos em TRL $(\mathrm{Sm} / \mathrm{La}<1)$, similares aos padrões de basaltos tipo NMORB. De acordo com esses autores, basaltos de bacias de 


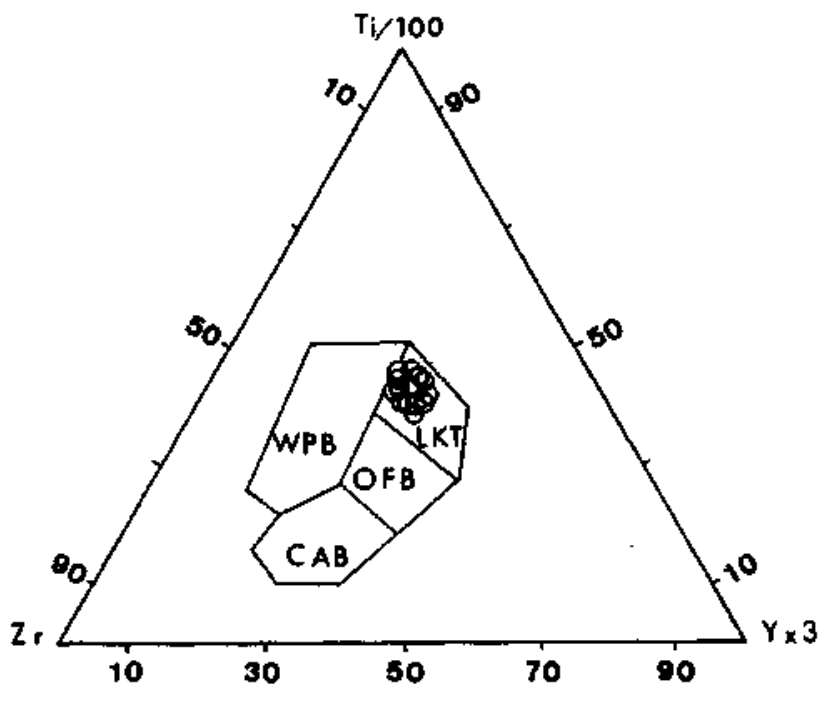

Figura 6 - Basaltos do Rio Itapicuru ocupando o campo destinado a toleitos de baixo K (LKT) no diagrama Ti/100-ZrY.3 proposto por Pearce \& Cann (1973). WPB (basaltos de entre-placas), OFB (basaltos de fundo oceânico) e CAB (basaltos cálcio-alcalinos)

Figure 6 - Ti/100 - Zr - Y.3 diagram (from Pearce \& Cann 1973) showing the Rio Itapicuru basalts in the low-K tholeiite field. WPB (within plate basalts), OFB (ocean floor basalts) and CAB (calc-alkaline basalts)

back-arc apresentam enriquecimento em TRL em relação às TRP, com razões $(\mathrm{La} / \mathrm{Lu})_{n}>1$, ou então razões $(\mathrm{La} / \mathrm{Lu})_{\mathrm{n}}$ aproximadamente iguais a 1. Ainda segundo esses autores, a ausência em bacias de back-arc de basaltos empobrecidos em TRL, à semelhança de basaltos do tipo N-MORB, pode ter duas explicações:

1. a inexistência nessas bacias de um manto fonte empobrecido, similar ao manto fonte que dá origem à maioria dos basaltos de cadeias mesoceânicas (valores altamente positivos de eNd), ou 2. a existência desse manto fonte empobrecido, sendo o magma gerado posteriormente submetido a fenômenos de contaminação crustal, com conseqüente diminuição dos valores de $\mathrm{Nd}$.

A freqüente ausência de basaltos com padrões empobrecidos em TRL mas com valores fracamente positivos de Nd nas bacias de back-arc parece apontar para a segunda hipótese.

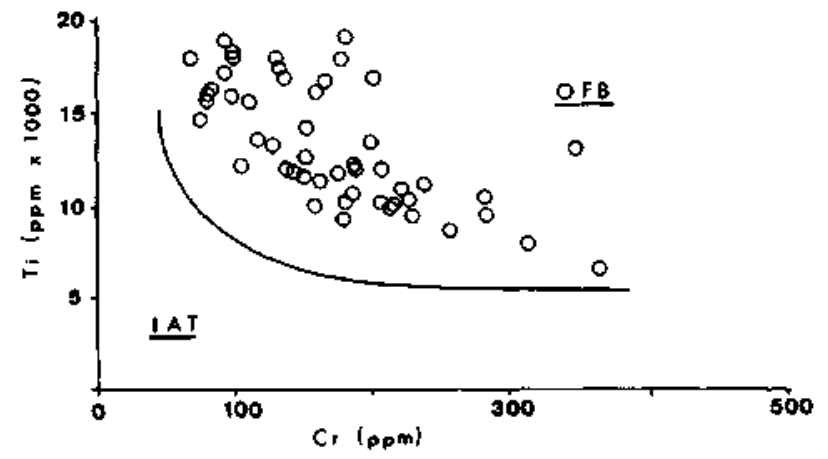

Figura 7a - Basaltos do Rio Itapicuru ocupando o campo destinado aos basaltos de fundo oceânico (OFB) no diagrama Ti-Cr proposto por Pearce (1975). IAT (toleitos de arcos de ilhas)

Figure 7a - Ti-Cr diagram (from Pearce 1975) showing the Rio Itapicuru basalts in the OFB (ocean floor basalts) field. IAT (island arc tholeiites)
As rochas basálticas do Rio Itapicuru, tanto os basaltos Tipo I com $(\mathrm{La} / \mathrm{Lu}) n$ aproximadamente igual a 1 , quanto os basaltos tipo II, com $(\mathrm{La} / \mathrm{Lu})_{\mathrm{n}}$ maior que 1 , possuem $\mathrm{Nd}$ positivo (+4), apontando para uma fonte empobrecida.

Tal comportamento geoquímico dos basaltos do Rio Itapicuru nos permite levantar a hipótese dos mesmos terem sido gerados num ambiente do tipo back-arc. Entretanto, uma interpretação baseada apenas nas características geoquímicas dessas rochas não é, de forma alguma, definitiva. Outros dados relativos à geologia regional, comportamento metamórfico e estrutural, assim como as rochas associadas (presença de lavas e piroclásticas félsicas, além de sedimentos elásticos grossos), dão maior suporte à essa interpretação, como será discutido mais adiante.

ROCHAS VULCÂNICAS FÉLSICAS Aspectos macro e microscópicos As rochas vulcânicas intermediárias e félsicas compreendem lavas e piroclásticas andesíticas a dacíticas que se situam na porção central da seqüência supracrustal, ocupando cerca de $25 \%$ da área de exposição do greenstone (Fig. 2). O contato entre essas rochas vulcânicas de natureza félsica e os vulcanites máficos nem sempre é observável. Quando aflorante, esse contato é por falhamento. Os derrames, são em sua maioria, porfiríticos, com fenocristais de hornblenda e/ou plagioclásio nas lavas andesíticas e fenocristais de plagioclásio e quartzo nas lavas dacíticas. Derrames afaníticos são raros. Lentes irregulares de lavas variolíticas são encontradas intercaladas nos derrames porfiríticos ou afaníticos.

As feições primárias dessas rochas estão muito bem preservadas, à exceção de alguns locais, onde as rochas foram submetidas a processos de cisalhamento. Em alguns afloramentos ao longo do Rio Itapicuru é possível observar linhas de fluxo primário e fraturas radiais de resfriamento brusco nas lavas andesíticas. Microscopicamente, foram reconhecidas feições texturais tais como arranjos pilotaxíticos e intersertais, golfos de corrosão em grãos de quartzo e quartzo bipiramidal.

Estas lavas foram, pelo menos em parte, afetadas pelos processos hidrotermais do evento metamórfico de fundo oceânico (Ml), com o desenvolvimento da paragênese albita+clorita+epidoto+sericita+carbonato+quartzo.

As piroclásticas compreendem lentes de tufos de cinza, tufos de cristais, tufos líticos lapilli, tufos vítreos e aglomerados vulcânicos.

Uma lente contínua de quartzo albitito (sedimento vulcanoquímico), contendo até $30 \%$ de sulfetos (pirita, arsenopirita e raramente esfalerita) ocorre na interface entre as rochas

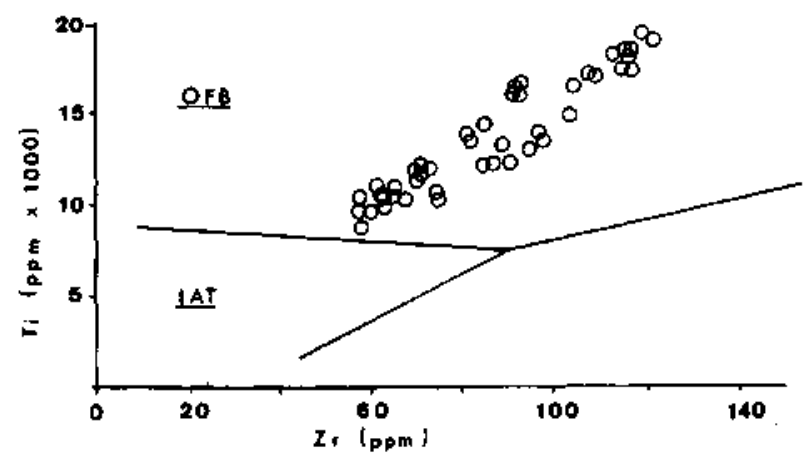

Figura $7 b$ - Basaltos do Rio Itapicuru ocupando o campo dos basaltos de fundo oceânico (OFB) no diagrama Ti-Zr proposto por Pearce \& Cann (1973), modificado por Garcia (1978). IAT (toleitos de arcos de ilhas)

Figure 7b - Ti-Zr diagram (from Pearce \& Cann 1973, modified by Garcia 1978) showing the Rio Itapicuru basalts in the OFB (ocean floor basalts) field. IAT (island arc tholeiites) 
vulcânicas intermediárias a félsicas e um pacote sedimentar sobrejacente (Fig. 2).

$\mathrm{O}$ arranjo espacial dessas rochas do domínio vulcânico félsico é zonado, com as lavas predominando na porção oeste do domínio e gradando, no sentido leste, para piroclásticas, vulcânicas epiclásticas e, por fim, vulcanoquímicas. Essa zonalidade pode ser decorrente de um controle paleotopográfico. As lavas e piroclásticas representariam a parte mais elevada e mais próxima do centro vulcânico enquanto as vulcânicas epiclásticas e as vulcanoquímicas teriam sido depositadas numa porção topograficamente rebaixada do terreno. As vulcânicas epiclásticas possuem natureza turbidítica, o que aponta para uma considerável e abrupta diferença de relevo entre o centro vulcânico félsico e a porção da bacia onde foram depositadas as rochas turbidíticas.

Os efeitos dos eventos M1 e M2 são também aqui observados, muito embora grande parte das feições primárias esteja preservada.

Predominam paragêneses da fácies xisto verde com o desenvolvimento de albita, clorita, carbonato, sericita, epidoto, quartzo e hematita. Na maioria dos casos, as reações metamórficas do evento M2 não mascararam totalmente as evidências do evento Ml. Nos aglomerados vulcânicos, por exemplo, os fragmentos tamanho bomba de lava andesítica possuem formato fusiforme, com bordas afaníticas de resfriamento. Essas bombas são uma das evidências dentro do pacote vulcânico félsico de que, pelo menos em parte, esse evento vulcânico se deu em ambiente sub-aéreo.

Geoquímica A análise química de amostras de lavas andesíticas e dacíticas aponta para a existência de um hiato de silica entre o vulcanismo máfico e o evento vulcânico félsico, como ilustrado no diagrama da figura 8 , caracterizando uma bimodalidade do vulcanismo.

Quando plotadas num diagrama do tipo AFM (Fig. 9), andesitos e dacitos configuram um trend geoquímico cálcioalcalino de diferenciação magmática.

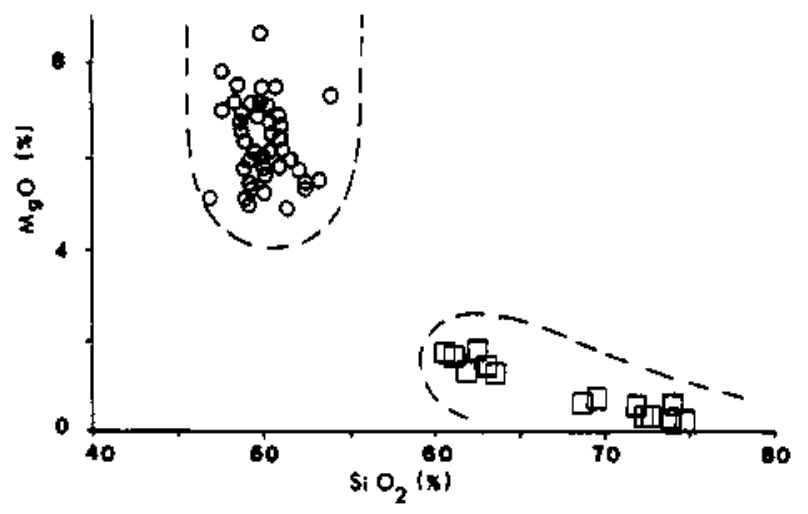

Figura 8 - Diagrama $\mathrm{MgO}-\mathrm{SiO}_{2}$ evidenciando o hiato de silica existente entre os vulcanitos máficos e félsicos do Rio Itapicuru. Círculos representam as vulcânicas máficas e quadrados as vulcânicas félsicas

Figure $8-\mathrm{MgO}-\mathrm{SiO}_{2}$ diagram showing the silica gap between the mafic volcanics (circles) and felsic volcanics (squares)

O padrão de distribuição das terras-raras, com curvas muito inclinadas no domínio das TRL (Fig. 10) e alta razão La/Yb, aponta para uma similaridade com andesitos de margens continentais ativas. Essa similaridade é também notada quando se observa o padrão de distribuição de elementos incompatíveis, de comportamento relativamente imóvel (Fig. 11), normalizados em relação a um ORG (ocean ridge granite), usando valores de normalização de Pearce et al. (1984).

Considerando que as características geoquímicas apontaram para um ambiente do tipo arco de margem continental

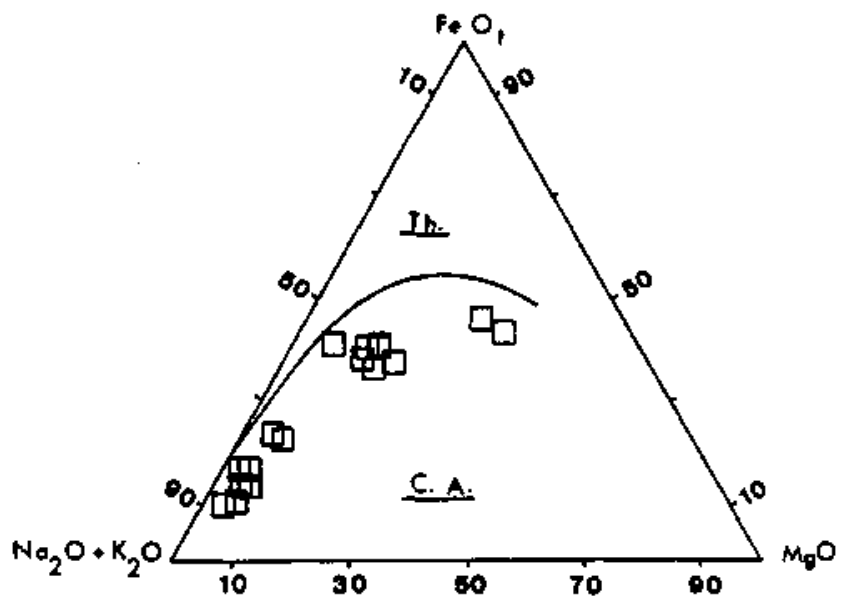

Figura 9 - Diagrama AFM mostrando o trend cálcio-alcalino desenvolvido pelas vulcânicas félsicas do Rio Itapicuru. CA (cálcio-alcalinas) e Th (toleitos)

Figure 9 - The AFM diagram, showing the calc-alkaline trend of the andesitic and dacitic lavas from the Rio Itapicuru Greenstone Belt. C.A. (calc-alkaline) Th (tholeiite)

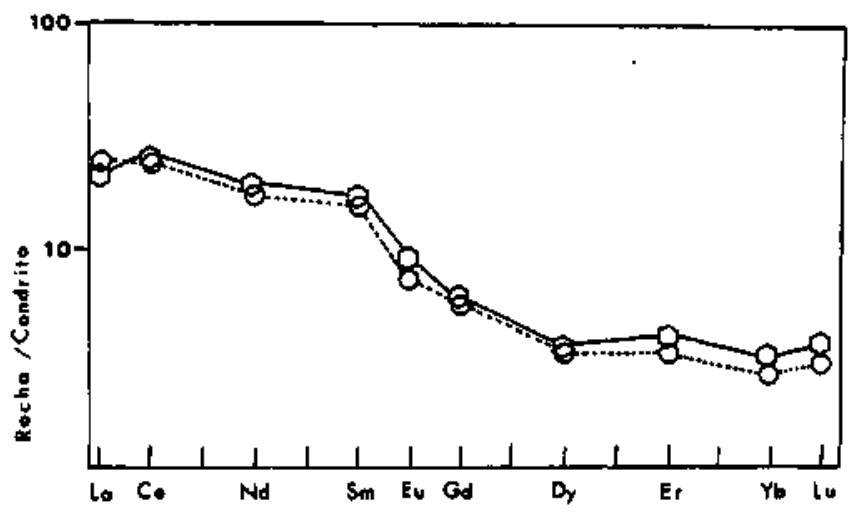

Figura 10-Valores normalizados de terras-raras de andesitos do Rio Itapicuru

Figure 10 - Chondrite-normalized rare earth elements pattern of the Rio Itapicuru andesites

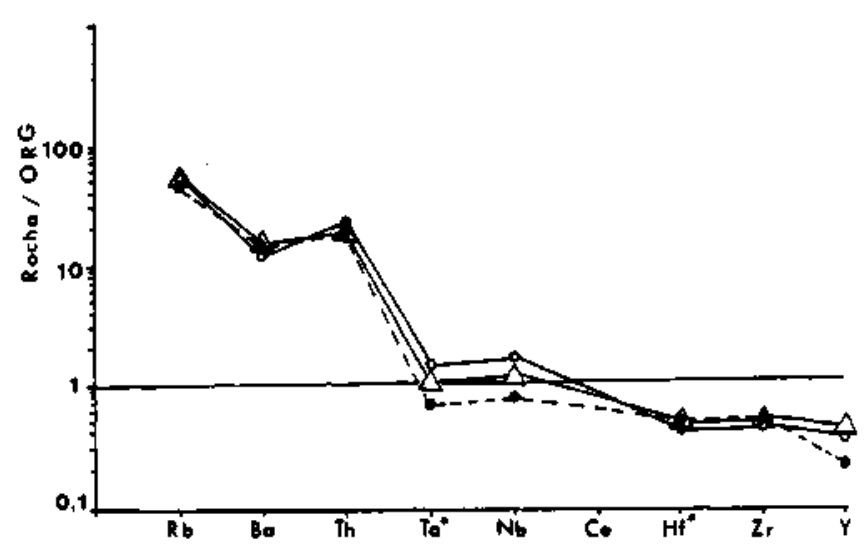

Figura 11 - Valores normalizados em relação a ORG (ocean ridge granite) de elementos incompativeis das rochas andesíticas do Itapicuru

Figure 11 - Spider-diagram of the felsic and intermediate lavas of the Rio Itapicuru Greenstone Belt, normalized to an ORG (ocean ridge granite)

para as rochas andesíticas e dacíticas. Silva (1987) realizou alguns cálculos petrogenéticos, na tentativa de definir a natureza da fonte dessas rochas. Nesse trabalho ficou demonstrado, tomando por base os teores de $\mathrm{Zr}, \mathrm{Y}, \mathrm{Nb}, \mathrm{Ni}$ e ETR, 
que as vulcânicas máfícas toleíticas e os vulcanites intermediários a félsicos não poderiam ter sido originados de uma mesma fonte magmática, através de processos de cristalização fracionada.

A possibilidade dessas rochas terem sido originadas a partir de líquidos derivados da fusão parcial da crosta continental pré-existente (embasamento gnáissico-migmatítico) foi igualmente descartada por Silva (1987), tendo em vista a baixa razão isotópica inicial de $\mathrm{Sr}(0,701)$ das lavas andesíticas e dacíticas.

Uma alternativa seria a derivação dessas rochas a partir da fusão parcial da crosta oceânica subductada e modificada, considerando o ambiente geotectônico no qual elas parecem ter sido geradas. Cálculos petrogenéticos demonstraram a viabilidade dessa hipótese, considerando $35 \%$ de fusão parcial de uma rocha quartzo eclogítica. Uma descrição pormenorizada desses cálculos pode ser encontrada em Silva (1987).

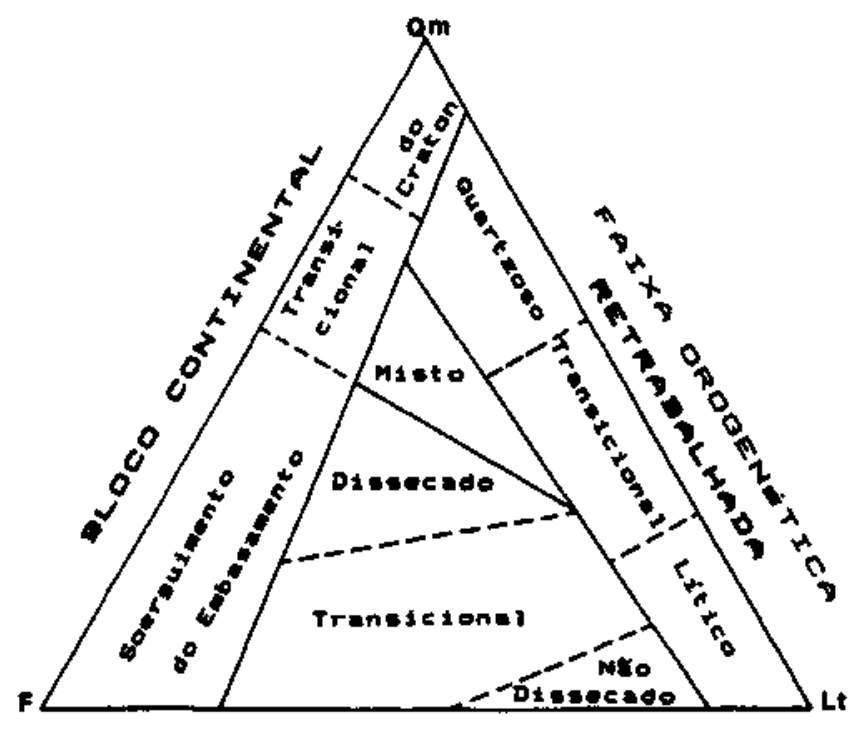

ARCD MAOMATICO

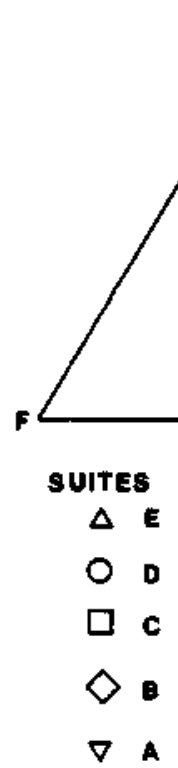

Figura 12 - Diagramas triangulares, de Dickinson et al. 1983, com as discriminações das áreas fontes de diferentes suites de rochas sedimentares do Rio Itapicuru. Q (quartzo), Qm (quartzo monocrístalino), Qp (quartzo policristalino), Qt $(Q m+Q p), F$ (feldspato), L (litoclastos), Lt $(Q p+L)$. Suíte A: sedimentos da porção centro-norte, ao longo do rio Itapicuru. Suítes B, C e D: sedimentos da porção sul do greenstone, região de Araci

Figure 12 - Dickinson et al (1983) diagram spoting the source areas of the clastic sediments of the Rio Itapicuru Greenstone Belt. Q (quartz), Qm (monocristaline quartz), Qp (policristaline quartz), Qt (Qm+Qp), F (feldspar), L (lithoclasts), Lt (L+Qp). Suite A: central northern sediments. Suites B, C and D: sediments from the southern portion of the Rio Itapicuru Greenstone Belt, Araci region
A rocha eclogítica seria o produto do metamorfismo de alto grau da crosta oceânica subductada, hipótese já anteriormente adotada por diversos autores (Green \& Ringwood 1968, Condie \& Harrison 1976, Condie 1976, Hawkesworth \& O'Nions 1977, Jahn et al. 1980) para explicar a origem de rochas andesíticas de ambientes orogenéticos.

Nesse caso, os andesitos do Rio Itapicuru teriam sido originados numa margem continental ativa, margem essa adjacente à bacia de extensão onde foram geradas as rochas basálticas toleíticas.

ROCHAS SEDIMENTARES Lentes de chert, jaspilitos e formações ferríferas são freqüentemente encontradas intercaladas nas lavas toleíticas, evidenciando a existência de períodos de pausa na atividade vulcânica.

Os sedimentos associados às vulcânicas félsicas são de natureza predominantemente elástica e muito raramente de

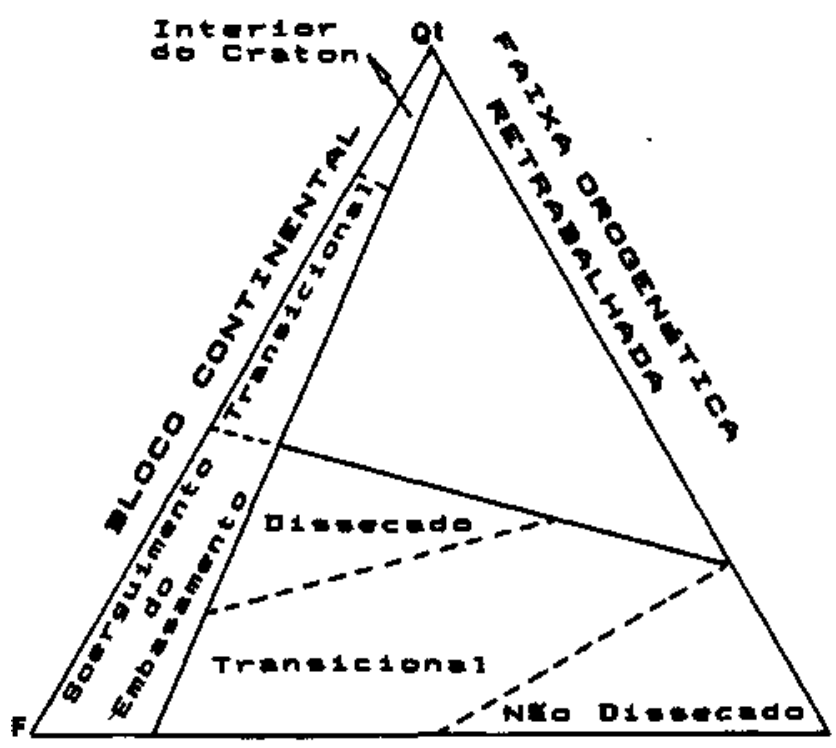

AMCD MAOMATICO

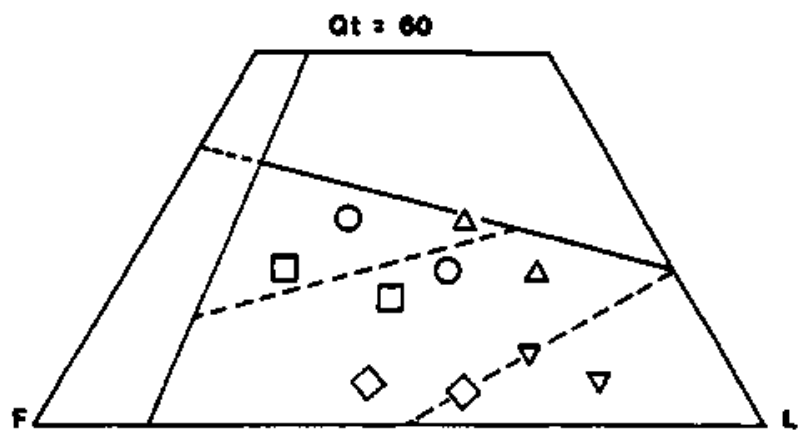


natureza química. Trata-se de rochas vulcânicas epiclásticas (conglomerados, arenitos, siltitos e folhelhos), cuja composição mineralógica aponta para um retrabalhamento das rochas piroclásticas andesítícas e daciücas. Estes sedimentos são ritmitos bem preservados, que exibem freqüentemente estruturas sedimentares, tais como foliação plana, estratificação cruzada e acamamento gradacional, evidenciando a sua natureza turbidítica.

Um trabalho recente realizado por Lebede \& Hoppe (1990), aplicando o método de Dickinson et al. (1983), tornou evidente que a sedimentação elástica dessa seqüência foi decorrente da dissecação de rochas vulcânicas félsicas. Nos diagramas da figura 12 aparece um nítido trend de sedimentos oriundos de um arco de ilha imaturo (undissected) para sedimentos oriundos de um arco maturo (dissected). De acordo com os estudos realizados por esses autores, os sedimentos elásticos precoces foram depositados como turbiditos em ambiente marinho profundo, onde se associaram a sedimentos químicos. Os sedimentos mais grossos, que predominam nas porções superiores da seqüência, teriam sido formados em ambiente marinho raso. Nestes sedimentos mais grossos foi detectada a presença de alguns clastos oriundos de rochas externas ao ambiente da bacia de deposição (rochas do embasamento gnáissico-migmatítico).

ROCHAS ULTRAMÁFICAS Apenas dois pequenos corpos ultramáficos foram até o momento identificados na seqüência. Esses corpos possuem posicionamento estratigráfico duvidoso, uma vez que suas relações de contato com as rochas encaixantes estão obliteradas por feições de cisalhamento.

Do ponto de vista petrográfico trata-se de peridotitos serpentinizados e carbonatizados, com texturas de cumulus ainda preservadas, evidenciadas pela presença constante de pseudomorfos de olivina. Entre os grãos de olivina observamse placas opticamente contínuas de clinopiroxênio e mais raramente uma massa fina recristalizada a clorita e óxidos de ferro, de possível natureza vítrea primária. $\mathrm{O}$ clinopiroxênio ocorre também em cristais finos aciculares em arranjo estrelar.

O quimismo dessas rochas possui similaridades com o de rochas de natureza komatiítica conhecidas da literatura, destacando-se, dentre outras feições, os elevados teores de $\mathrm{MgO}$ variando entre 28 e $33 \%$, teores de $\mathrm{Ti}$ inferiores a $0,3 \%$, conteúdo de álcalis abaixo de $1 \%$, razões $\mathrm{Al}_{2} \mathrm{O} / \mathrm{TiO}_{2}$ e $\mathrm{Ti} / \mathrm{Zr}$ condríticas, além de altos teores de $\mathrm{Ni}$ e $\mathrm{Cr}$.

Nos diagramas das figuras 13 e 14, é possível observar o comportamento das ultramáficas do Rio Itapicuru comparativamente a amostras de cumulados peridotíticos komatííticos de outras partes do mundo (Nesbitt et al. 1979, Condie 1981, Arndt 1977).

DISCUSSÃO Os dados petrográficos e geoquímicos das rochas basálticas, acima sumarizados, dão suporte à proposição de um modelo de evolução da seqüência supracrustal do greenstone belt do Rio Itapicuru, num ambiente do tipo bacia de back-arc (Fig. 15). Igualmente favorável a esse modelo são os dados geocronológicos e isotópicos, o padrão de metamorfismo, o plutonismo, bem como outros aspectos da geologia regional.

A existência de uma plataforma continental, anterior à bacia, é confirmada pela idade arqueana $(2,9 \mathrm{Ga}$, Gáal et al. em elaboração) obtida nas rochas gnáissico-migmatíticas nas quais as supracrustais estão encravadas.

Isócronas $\mathrm{Pb}-\mathrm{Pb}$ e idades modelo Sm-Nd (Silva, em preparação), revelaram a idade proterozóica inferior da seqüência supracrustal $(2,1 \mathrm{Ga}$. para os andesitos e 2,2 Ga para os basaltos). $\mathrm{O}$ fechamento da bacia, concomitante à colocação de domos graníticos gnáissicos (Silva 1987, Davison \& Matos 1988), parece ter ocorrido em torno de $1,8 \mathrm{Ga}$, considerando a idade $\mathrm{Rb} / \mathrm{Sr}$ obtida para essas rochas (Gáal et al, em elaboração).

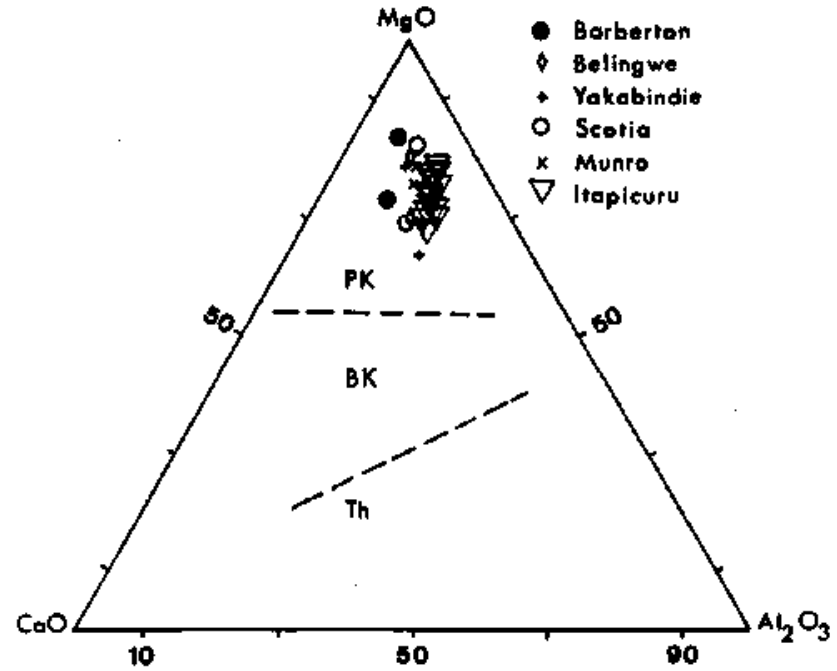

Figura 13 - Diagrama $\mathrm{CaO}-\mathrm{MgO}-\mathrm{Al}_{2} \mathrm{O}_{3}$, onde as ultramáficas do Rio Itapicuru plotam juntamente com amostras de outros greenstone belts (Arndt 1977, Nesbitt et al. 7979, Condie 1981. PK (perídotitos komatifticos), BK (basaltos komatiíticos), Th (toleitos)

Figure $13-\mathrm{CaO}-\mathrm{MgO}-\mathrm{Al}_{2} \mathrm{O}_{3}$, diagram showing the ultramafics from the Rio Itapicuru plotting together with komatiitic rocks from others Greenstone Belt sequences (Nesbitt et al 1979, Arndt 197, Condie (1981); PK (komatiitic peridotites), BK (komatiitic basalts), Th (tholeiites)

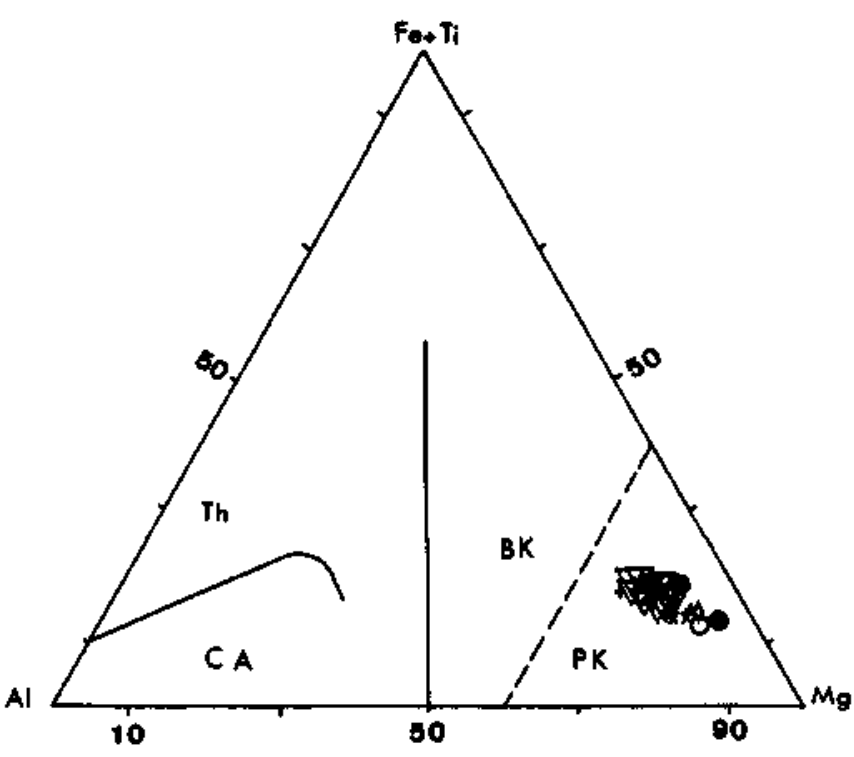

Figura 14 - Rochas ultramáficas do Rio Itapicuru, no diagrama de Jensen, ocupando o campo destinado a ultramáficas komatiíticas. Símbolos e legenda como na figura 13. CA (cálcio-alcalina)

Figure 14 - Jensen Plot for the Rio Itapicuru ultramafic rocks. Simbols and legend as in fiugre 13. CA (calc-alkaline)

O evento metamórfico regional, responsável pelo desenvolvimento de uma zonalidade metamórfica na seqüência, não ultrapassou os limites da fácies anfibolito de metamorfismo, com temperaturas máximas da ordem de $650^{\circ} \mathrm{C}$ e mínimas de $300^{\circ} \mathrm{C}$ e pressões variáveis entre 2 e 4 kbar (Silva 1983,1987). Esse evento metamórfico teve seu pico entre 1,8-2,0 Ga, considerando a idade dos domos sintectônicos, coincidindo com o evento Transamazônico, largamente discutido na literatura geológica.

O plutonismo que afetou a seqüência supracrustal foi predominantemente granítico. São observados granitóides pós- 


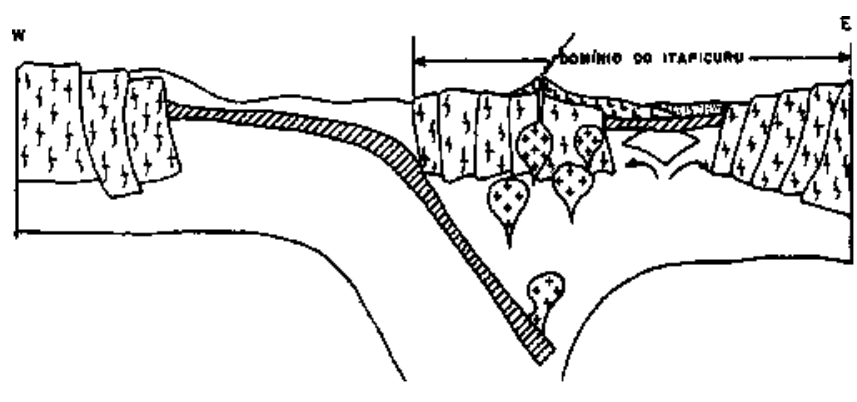

LE EENDO

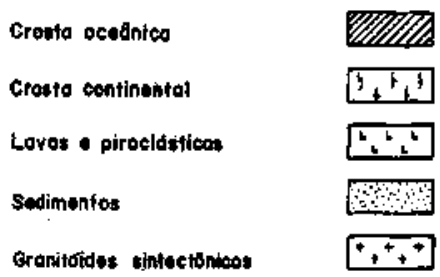

Figura 15 - Proposta de um modelo de evolução geotectônica para o Greenstone Belt do Rio Itapicuru (Bahia)

Figure 15 - Proposed geotectonic evolution model for the Rio Itapicuru Greenstone Belt (Bahia)

tectônicos de pequenas dimensões e granitóides elipsoidais, de margens foliadas, sin-tectônicos. De acordo com Silva (1987) os corpos sintêctõnicos são de quimismo calcio-alcalino, geneticamente correlates ao evento vulcânico félsico.

Os trabalhos de Davison et al. (1988) e Davison \& Matos (1987) deixam evidente a estreita relação entre a colocação dos domos graníticos sin-tectônicos e a deformação F2 da seqüência supracrustal.

A integração dos dados referentes ao plutonismo granítico e ao metamorfismo nos permite concluir que ambos os eventos são concomitantes, provavelmente relacionados ao fechamento da bacia de deposição.

CONCLUSÕES As feições litoestratigráficas e litogeoquímicas, o padrão de metamorfismo e deformação e os resultados preliminares de geocronologia da seqüência vul- canossedimentar do Rio Itapicuru são similares às descritas na literatura geológica, como típicas de algumas seqüências vulcanpssedimentares formadas em ambientes modernos do tipo bacias do tipo back-arc, tais como o Complexo Rocas Verdes, no Chile (Tarneyeffl/. 1976) e Scotia Sea (Weaver et al 1979): Dentre os aspectos mais contundentes dessa similaridade, destacam-se:

1. a presença dominante de basaltos toleíticos de fundo oceânico, ricos em ferro;

2. o vulcanismo calcio-alcalino, com características geoquímicas compatíveis com as de vulcanitos de margens continentais ativas;

3. a presença de granitos sintêctõnicos, geneticamente correlatos aos andesitos;

4. a existência de uma fase subaérea do evento vulcânico félsico, com a geração de diferentes tipos de rochas piroclásticas;

5. a natureza turbidítica dos sedimentos elásticos e sua origem relacionada à dissecação de um arco vulcânico;

6. a presença de sedimentos marinhos profundos intercalados nas rochas vulcânicas máfícas;

7. o metamorfismo predominantemente de baixo grau;

8. a existência de um evento inicial de deformação, de natureza tangencial;

9. o padrão de deformação sinformal, concomitante à colocação dos domos graníticos e ao pico do metamorfismo regional.

Bacias do tipo back-arc são geradas por rifteamento, simples ou múltiplo, na parte posterior de arcos de ilhas, em ambientes colisionais (Tamaki 1985). Esse rifteamento é originado a partir de um movimento divergente (extensional), gerado na placa sobrejacente, continental ou oceânica, em decorrência do movimento de subducção (Chase 1978, Uyeda \& Kanamorí 1979).

De acordo com essa definição, a caracterização do greenstone belt do Rio Itapicuru como uma bacia do tipo back-arc implica na existência de um ambiente de colisão do tipo arcocontinente no Proterozóico Inferior, na porção nordeste do Cráton do São Francisco, Estado da Bahia.

Agradecimentos A autora agradece o trabalho de revisão, as críticas e sugestões apresentadas pelos professores Johildo Figueiredo Barbosa e Umberto Raimundo Costa, ambos do Curso de Pós-Graduação em Geologia do Instituto de Geociências da UFBA e aos dois revisores anônimos da RBG.

\section{REFERÊNCIAS BIBLIOGRÁFICAS}

ALMEIDA, F.F. 1977. O Cráton do São Francisco. Rev. Bras. Geoc., 7(4):349-364

SILVA, F.C. \& MATOS, FM.V. 1991. Economic geology and structural controls of orebodies from the medium Itapicuru gold district: Rio Itapicuru Greenstone Belt, Bahia, Brazil. In: SYMP. BRAZIL GOLD' 91. Belo Horizonte, 1991. Proceedings... p. 629-635.

ARNDT, N.T. 1977. Thick layered peridotit-gabbro lava flows in Munro Township. Can. J. Earth Sci., 14:2620-2637.

B VSR 1981. Basaltic Volcanism in the Terrestrial Planets. New York, Pergamon Press. 1286 p. (Basaltic Volcanism Study Project).

CHASE, C.G. 1978. Extension behind island arcs and motions relative to hot spots. J. Geoph. Research, 83:5385-5387.

CONDIE, K.C. 1976. Trace element geochemistry of Archean Greenstone Belts. Earth Sci. Rev., 12:393-417.

CONDIE, K.C. 1981. Archean Greenstone Belts. In. Developments in Precambrian Geology, 3. Amsterdam, Elsevier. $434 \mathrm{p}$

CONDIE, K.C. \& HARRISON, N.M. 1976. Geochemistry of the archaean bulawayan Group, Midlands Greenstone Belt, Rhodesia. Precambr. Res., 3:253-271.

DAVISON, I. \& MATOS, F.M.V. 1987. Basement or intrusion? The Ambrósio Dome, Rio Itapicuru Greenstone Belt, Bahia, Brazil. Rev. Bras. Geoc., 17:442-449.

DAVISON, I.; TEIXEIRA, J.B.G.; SILVA, M.G.; ROCHA NETO, M.B; MATOS, F.M.V. 1988. The Rio Itapicuru Greenstone Belt, Bahia, Brazil: structure and stratigraphical outline. Precambr. Res., 42:1-17.
DICKINSON, W.; BEARD, L.S.; BRAKENRIDGE, G.R.; ERJAVEC, J.L.; FERGUSON, R.C.; INMAN, K.F.; KNEPP, R.A.; LINDBERG, F.A.; RYBERG, P.T. 1983. Provenance of North American Phanerozoic sandstones in relation to tectonic setting. Geol. Soc. Am. Bull., 94:222-235

GARCIA, M.0.1978. Criteria for identification of ancient volcanic arcs. Earth Sci. Rev., 14:147-165.

GREEN, T.H. \& RINGWOOD, A.E. 1968. Genesis of the calc-alkaline igneous rock suite. Contrib. Mineral. Petrol, 18:105-162.

HAWKESWORTH, C.J. \& O'NIONS, R.K. 1977. The petrogenesis of some Archean volcanic rocks from southern Africa. J. Petrol., 18:487-520.

HAWKESWORTH, C.J.; O'NIONS, R.K.; PANKHURST, R.J.; HAMILTON P.J; EVENSON, N.M. 1977. A geochemical study of island arc and back arc tholeiites from the Scotia Sea. Earth Planet. Sci.Lett., 36:253-262.

J AHN, B-M. 1986. Mid-ocean ridge or marginal basin origin of the East Taiwan ophiolite: chemical and isotopic evidence. Contrib. Mineral. Petrol, 92:194-206.

JAHN, B-M.; AUVRAY, B.; BLAIAS, S.; CAPDEVILA, R.; CORNICHET, J.; VIDAL, F; HAMEURT, J. 1980. Trace element geochemistry and petrogenesis of Finish greenstone belts. J. Petrol, 21:201-244.

LEBEDE, S. \& HOPPE, A. 1990. Os sedimentos do Greenstone Belt do Rio Itapicuru. In. CONGR. BRAS. GEOL., 36. Natal, 1990. Resumo das Comunicações... Natal, SBG. p. 354.

MIYASHIRO, A. 1961. Evolution of metamorphic belts. J. Petrol, 2:277-311.

NESBITT, R; SUN, S.S.; PURVIS, A. 1979. Komatiites: geochemistry and genesis. Can.. Mineral., 17:165-186. 
PEARCE, J.A. \& CANN, J.R. 1973. Tectonic setting of basic volcanic rocies determined using trace element analysis. Earth Planet. Sci. Lett., 19:290-300.

PEARCE, J.A. 1975. Basalt geochemistry used to investigate past tectonic environment on Cyprus. Tectonophysics, 25:41-67.

PEARCE, J.A., HARRIS, N.B.W.; TTNDLE, A.G. 1984. Trace element discrimination diagrams for the tectonic interpretation of granitic rocks. J. Petrol, 25:956-983.

PEARCE, T.H.; GORMAN, B.E.; BIRKETT, T.C. 1975. The $\mathrm{TiO}_{2}-\mathrm{K}_{2} \mathrm{O}-\mathrm{P}_{2} \mathrm{O}_{3}$ diagram: a method of discriminating between oceanic and non-oceanic basalts. Earth Planet. Sci. Lett., 24:419-426.

SILVA, M.G. 1983. A Seqüência Vukanossedimentar do Médio Rio Itapicuru, Bahia: Caracterização Petrográfica, Considerações Petrogenéticas Preliminares e Zoneografia Metamórfica. Salvador. 88 p. (Dissertação de Mestrado, IG/UFBa).

SILVA, M.G. 1987. Geochemie, Petrologie und Geotektonische Entwicklung Eines Proterozoischen Grunsteingurtels: Rio Itapicuru, Bahia, Brasil. Alemanha. 179 p. (Tese de Doutorado, Geologisches Institui der Universitaet).

SOUNDERS, A.D. \& TARNEY, J. 1979. The geochemistry of basalts from a back-arc spreading center in East Scotia Sea. Geochim. Cosmochim. Acta, 43:555-572.
TAKEUCHI, H. \& UYEDA, S. 1965. A possibility of present day regional metamorphism. Tectonophysics, 2:59-68.

TAMAKI, K. 1985. Two modes of back-arc spreading. Geology, 13:475-478.

TARNEY, J.; DAZIEL, J.W.D.; DE WTT, M. J. 1976. Marginal basin 'Rocas Verdes' complex from S. Chile: a model for Archaean Greenstone Belt formation. In. B.F. Windley, ed. The Early History of the Earth. London, Wileylnterscience.p. 131-146.

UYEDA, S. \& KANAMORI, H. 1979. Back-arc opening and the mode of subduction. J. Geoph. Research, 84:1049-1062.

WEAVER, S.D.; SAUNDERS, A.D.; PANKHURST. R.J.; TARNEY, J. 1979. A geochemical study of magmatisra associated with the initial stages of back arc spreading. Contrib. Mineral. Petrol, 68:151-169.
MANUSCRITO A706 Recebido em 3 de setembro de 1991 Revisão do autor 3 de janeiro de 1992 Revisão aceita em 18 de fevereiro de 1992 